\title{
Study of Beef Availability Potential in Yogyakarta Special Province (DIY) through Multi Criteria Analysis (MCA) Model by Spatial Geographic Information System
}

\author{
Dwi Aulia Puspitaningrum,2*, Masyhuri ${ }^{3}$, Slamet Hartono ${ }^{3}$, Jamhari $^{3}$ \\ ${ }^{1}$ Program Pasca Sarjana Pertanian. Minat Ekonomi Pertanian, Fakultas Pertanian, \\ Universitas Gadjah Mada, Jl. Flora, Bulaksumur, Yogyakarta 55281, Indonesia \\ 2Program Studi Agribisnis, Fakultas Pertanian, Universitas Pembangunan Nasional "Veteran", Jl. Lingkar Utara 104 \\ Condongcatur, Depok, Sleman, Yogyakarta 55281, Indonesia \\ 3,4Departemen Sosial Ekonomi Pertanian dan Agribisnis, Fakultas Pertanian, Universitas Gadjah Mada, Jl. Flora, \\ Bulaksumur, Yogyakarta 55281, Indonesia \\ *Email: auliayk@yahoo.com, dwi.aulia.p@mail.ugm.ac.id
}

Submisi: 11 Oktober 2017; Penerimaan: 5 Februari 2018

\begin{abstract}
The increasing human population and income per capita in Indonesia have many impacts to the demand of food, not only staple food but also the secondary food too, including meat and beef demand. Based on data from Central Statistics Bureau of 1995-2016, beef demand in Indonesia has been increasing. This condition must be anticipated by preparing the supply, especially the availability of beef in Daerah Istimewa Yogyakarta province. In Yogyakarta city, one of the regencies of DIY, the demand rate grows by 3.2\%/year, higher than the supply growth rate by 2.08 $\% / y e a r$. This gap needs to be thought through the case of scarcity of beef on the market. This study aimed to identify the potential of supply in five parameters i.e.: beef population, the availability of semen for artificial insemination (IB), the availability of livestock feed plants (HMT), the number of cows that enter DIY, and the number of cows that exit from DIY. A model Spatial Geographic Information Systems (SGIS) has been used in this study. The study revealed the most potential area for the development of beef agribusiness, based on the availability side, was Gunung Kidul Regency, and the less potential was Yogyakarta municipality.
\end{abstract}

Keywords: Beef meat; GIS; multi criteria; potential; spatial

\section{INTRODUCTION}

Indonesian population has always been increasing every year, and currently reaches 250 million (BPS, 2016). The population increase also increases demand for food, both carbohydrate-based staple food and protein-based food and other nourishments such as meat. Beef is part of animal protein supply which experience increasing demand every year. The demand increase is not only due to the increase of population but also due to the increase of income per capita every year. Per capita income increase has made people not only shop for basic needs, but also for support needs, including increased quality of products purchased.

Yogyakarta Special Region (DIY), one of the provinces in Indonesia is a miniature Indonesia because it is the city of students and one of Indonesia's main tourist destinations. The growing number of hotels, inns, boarding houses, and the proliferating food stalls, diners, restaurants, food courts, and coffee shops have increased the demands for food supplies, including beef.
The demand for beef downstream needs to be fulfilled by improving the supply upstream. BPS' data show that for 21 years since 1995 up to 2016, the demand for beef has always been increasing. The increase rate in the period reaches $3.2 \%$ annually, as can be seen in Figure 1.

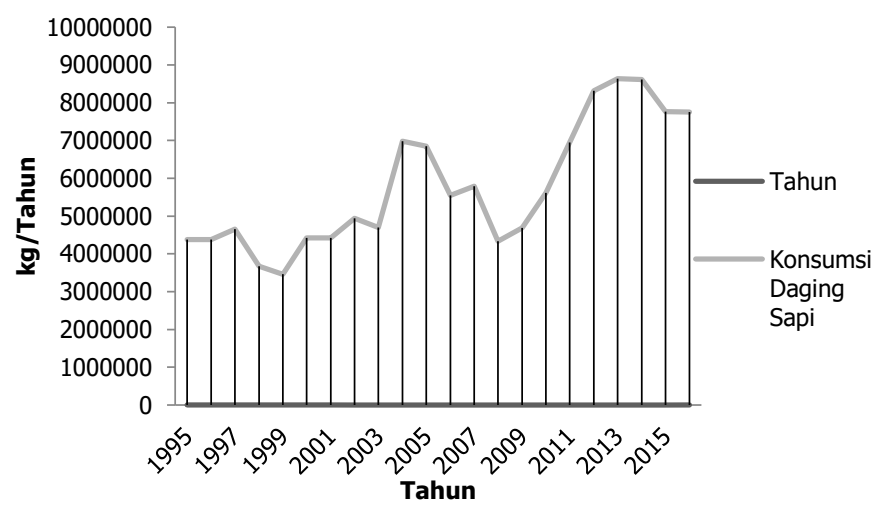

Figure 1. Beef demand chart per regency in DIY, 19952016

Source: Susenas, Badan Pusat Statistik (BPS) several years processed (2017) 
In order to fulfill the demand for beef, there are strategic steps that need to be taken on the supply side, so that beef availability in DIY can be maintained, therefore, market would run normally, and market equilibrium is maintained. Beef demand in 1995 was $4,383,380 \mathrm{~kg} /$ year, it increased to $6,849,456 \mathrm{~kg} / \mathrm{year}$ in 2005, and increased further to 7,765,767 kg/year in 2015. Regions with highest demand for beef are in Sleman area, with $31 \%$ share of beef demand in DIY.

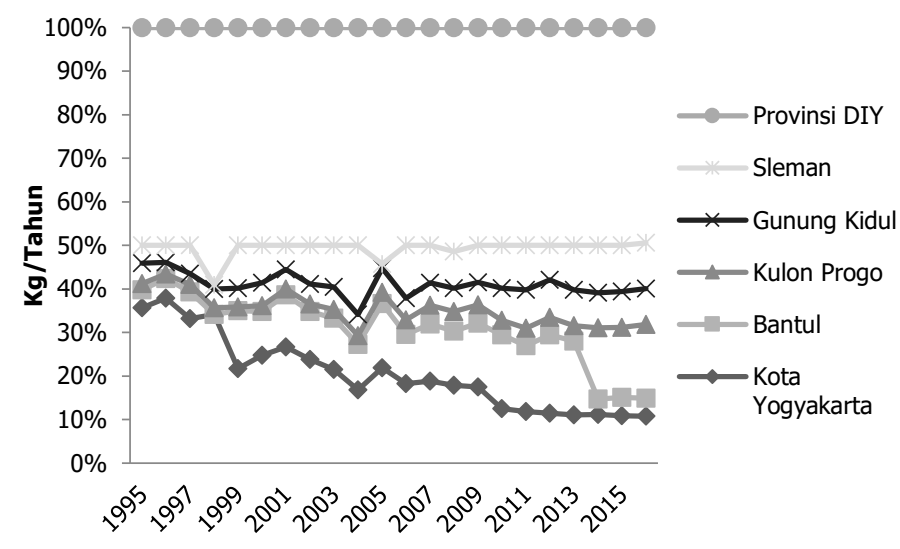

Tahun

Figure 2. DIY beef production chart 1995-2016,

Source: DIY Agricultural Office and BKPP DIY, several years processed (2017)

Whereas on the supply side, based on beef production data for 21 years 1995-2016, it is shown that there has been an increase every year, from 5,134,133 $\mathrm{kg}$ in 1995 , to $6,069,136 \mathrm{~kg}$ in 2005 , to $7,695,767 \mathrm{~kg}$ in 2015. Kulon Progo regency has the highest beef production rate in DIY with a production contribution of $34.25 \%$ for DIY province. The second highest in DIY is Sleman regency with a share of $21.214 \%$ for DIY province.

Fulfillment of beef supply to balance the demand in DIY must be anticipated by paying attention to the determining parameters onb the supply side. The parameters are influential factors in increasing beef production in DIY. The influential factors include cattle population in DIY; availability of semen or artificial insemination (IB); availability of fodder (HMT); number of beef cattle entering DIY and number of cattle leaving DIY. The five parameters are used in analyzing DIY region's potential to fulfill beef availability. By knowing the potential of each region in DIY, a portrait of beef availability will be obtained and policies can be formulated towards developing beef agribusiness in DIY. One of the ways to achieve a clear figure in each regency or municipality is by potential mapping. Knowing the potential of every area in DIY will provide a portrait of beef availability so that a policy can be formulated in developing beef agribusiness. One of the ways to determine the clear description in every regency/municipality in DIY is by mapping the potential using an analysis of Geographical Information System.
Kuncoro (2002) mentioned that the growth of awareness on the limitation of traditional location theory has pushed the emergence of new paradigms in regional and urban economics, which is called new geographical economics. One of the main trends in this new paradigm is the use of Geographical Information System (SIG). SIG is an analytical tool to identify locations of industry (in this research, the locations of agricultural industry), and in which areas agricultural commodities are clustered spatially (Akinci et al., 2013).

SIG is basically a special kind of information system which focuses on the representation and manipulation of geographical reality. SIG transforms data into information by integrating a variety of data, applying a focus analysis, and presenting output in order to support decision making (Juppenlatz and Tian, 1996). According to Esri (2004) in Irwansyah (2013), SIG is a system which regulates, analyzes, and presents geographical information. Computer provides storage, manipulation, and display of spatial data in large number, which will be displayed in digital form. The components which develop a geographical information system are hardware, software, data, method, and people (users). SIG's ability to store, analyze, map, and model has pushed a vast application over various disciplines, from information technology to socialeconomy or analysis related with population (Neidertsssceider et al., 2014).

SIG can be the software for experts who work in agriculture, because it offers a high ability as the tool for management, analysis, and research on agricultural resources (Neuwirth, 2015). The ability includes connecting objects in a map as basic data, combining graphical display with data of the problem, and functional analysis. Objects in a map unit can be derived or taken into individual maps or into thematic maps. The use of SIG in this research focuses on the areas that become the research objects and identification of graphical forms in parameter mapping used, namely DIY's beef cattle (unit), availability of DIY-made semen for artificial insemination (pack), availability of green pasture for DIY cattle (hectare), number of cattle entering DIY area (unit) and number of cattle leaving DIY area (unit). Integration between agriculture and SIG is a good means for literature study, data collection, analysis and synthesis (Chomitzs dan Gray, 2010). Additionally, making a model based on such an integration is an effective way to perform planning, especially in its application in managing agricultural resources due to different characteristics of areas with varying landscapes (Zhang, 2015). This enables SIG to perform analysis or modeling needed by decision makers. Based on the background mentioned above, this research is conducted. 


\section{RESEARCH METHOD}

The research method used to approach the objective is Spatial Geographical Information System with a Multi Criteria Analysis (MCA) method approach. MCA is generally defined as a way to make a decision and a mathematical device which enables comparison from various alternatives or scenarios based on many, often conflicting, criteria, in order to provide clues for decision makers to take fair/objective actions (Chakkar and

Mousseau, 2007), whereas according to Dodgson et al. (2009) it is used to view complex problems intended as the means for thinking in making decisions. The flow chart in Figure 3 shows the general scheme of MCA analysis.

Spatial MCA analysis using ILWIS software combines spatial and non-spatial criteria to obtain the best selection result and is graphically presented with ArcGIS 10.4.1. Schematically, the multi criteria approach used is displayed in Figure 3.

The steps in Spatial Multi Criteria Analysis are: (1) determining the objective; (2) criteria (factors/constraints) identification and grouping; (3) scoring for each criterion; (4) score standardization for criteria; (5) weighting for criteria; (6) location suitability map; and (7) decision making (optional). In detail, the procedure can be explained in Table 1.

In multi criteria analysis, there are 2 types of standardization, namely maximum and internal standardization. The formula for maximum standardization is shown in Equation 1.

$$
\begin{aligned}
& x=\frac{\text { score }}{\text { highest score }} \text { if the criteria is benefit }(+) \\
& x=1-\frac{\text { score }}{\text { highest score }} \text { if the criteria is cost }(-)
\end{aligned}
$$

Whereas for interval standardization the formula is as follows:

$$
\begin{aligned}
& x=\frac{\text { score-lowest score }}{\text { highest score- lowest score }} \text { if the criteria is benefit }(+) \\
& x=1-\frac{\text { score-lowest score }}{\text { highest score- lowest score }} \text { if the criteria is cost }(-)
\end{aligned}
$$

This research investigates the natural resource potential in each region of DIY for cattle-based enterprise development in DIY, which includes cattle beef population in DIY, availability of semen of artificial insemination (IB), availability of fodder (HMT), number of cattle entering DIY, and number of cattle leaving DIY. The five parameters are used in investigating DIY's potential in fulfilling beef availability. The same thing has been performed by Chomitz (2010) who stated that determining the region's potential can be conducted by exercising productive resource use according to evaluation objective.

The data used in spatial analysis using Geographical Information System in the form of administrative map of Yogyakarta Special Region. The administrative map of regencies and municipality in DIY is used as the basis of making a spatial map to determine and compare regions with the highest and lowest potential, to be used in policy-making according to the expected objective (Tarigan, 2008).

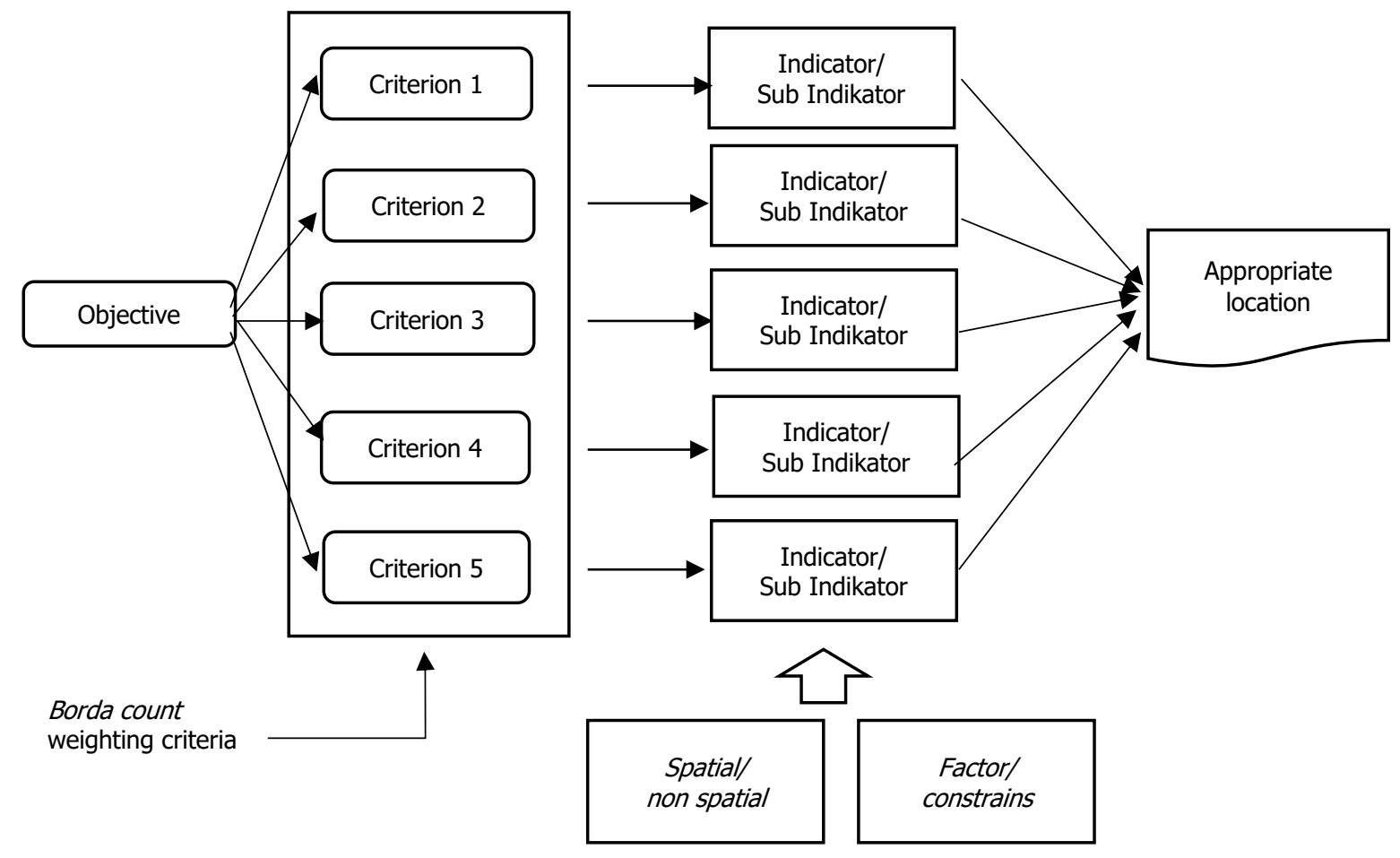

Figure 3. Multi Criteria Analysis (MCA) scheme on beef availability in DIY, 2017 
Table 1. Analysis procedure in Geographical Information System beef availability in DIY

\begin{tabular}{|c|c|}
\hline Procedure & Activity \\
\hline Data Collection & $\begin{array}{l}\text { a. Compiling size data of administrative area mapping based on number of beef cattle and potential } \\
\text { rumination pasture area width and per regency in DIY. Consisting of } 4 \text { regencies and } 1 \text { municipality. }\end{array}$ \\
\hline $\begin{array}{l}\text { Initial data } \\
\text { processing }\end{array}$ & $\begin{array}{l}\text { a. Grouping of beef cattle population data } \\
\text { b. Grouping of semen for artificial insemination (IB) data } \\
\text { c. Grouping of cattle pasture or fodder (HMT) data } \\
\text { d. Grouping of slain cattle data } \\
\text { e. Grouping of cattle coming to DIY data } \\
\text { f. Grouping of cattle leaving DIY data }\end{array}$ \\
\hline $\begin{array}{l}\text { Multi criteria } \\
\text { data base } \\
\text { construction }\end{array}$ & $\begin{array}{l}\text { a. Creating distribution matrix } \\
\text { b. Transferring matrix data into map presentation data source (scalogram) }\end{array}$ \\
\hline $\begin{array}{l}\text { Spatial analysis } \\
\text { and study }\end{array}$ & $\begin{array}{l}\text { a. Data calling based on cattle beef population distribution, IB data, HMT data, cattle entering DIY data, } \\
\text { and cattle leaving DIY data } \\
\text { b. Making patterns and describing them on the map based on analysis target distribution location. }\end{array}$ \\
\hline $\begin{array}{l}\text { Multi criteria } \\
\text { analysis }\end{array}$ & $\begin{array}{l}\text { a. Making various processed beef data with five types of criteria in each target region, namely Sleman } \\
\text { regency, Bantul regency, Gunung Kidul regency, Kulon Progo regency, and Yogyakarta municipality }\end{array}$ \\
\hline $\begin{array}{l}\text { Graphical } \\
\text { presentation }\end{array}$ & $\begin{array}{l}\text { Making map overlay based on cattle potential distribution in each region with multi criteria and mapping } \\
\text { graphics. } \\
\text { Making map layout. }\end{array}$ \\
\hline $\begin{array}{l}\text { Conclusion and } \\
\text { policy }\end{array}$ & $\begin{array}{l}\text { a. Drawing conclusion on result data obtained and making analysis on the policy obtained for research } \\
\text { purposes }\end{array}$ \\
\hline
\end{tabular}

Source: Modification model of Jones's Theory (1997) in Kuncoro (2002)

The end result obtained is a description according to the best scenario in every regency and municipality in Yogyakarta Special Region. The end result is obtained based on the potential value with the weighting throughout all region in DIY in fulfilling beef for DIY.

\section{RESULTS AND DISCUSSION}

Multi criteria analysis (MCA) approach used in this study includes 5 criteria or parameters on the supply side of the beef availability of supply chain in DIY region. The data used are a combination between secondary and primary data in every region based on annual data from 2005 to 2016 . Every criterion is subjected to an analysis in every region in the regency/municipality. In detail, the calculation result of MCA analysis per parameter of criteria from 1 to 5 .

\section{Criterion 1 (A1) = Beef population in DIY criterion}

Beef population based on data from 2005 to 2016 in Yogyakarta Special Region is found the most in Gunug Kidul regency with an average population of 134,346 cattle/year, followed by Bantul regency with 57,030 cattle/year, and consecutively after that Kulon Progo regency with 52,340 cattle/year, Sleman regency 49,461 cattle/year and the lowest beef cattle population is in Yogyakarta municipality with an average of 219 cattle/year, as shown in Figures 4 and 5.

Next from Figure 4 can be graphically described using Arch GIS 10.4.1 with spatial data per regency region in DIY using MCA model.

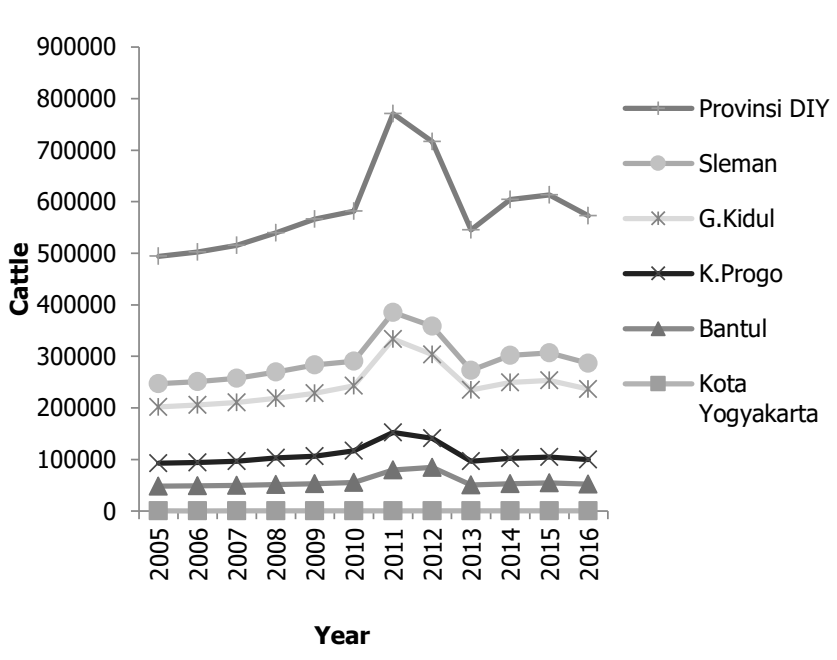

Figure 4. Beef cattle per regency in DIY between 2005 2016 (processed)

Source: BPS and Agricultural Office DIY and BKPP DIY. Data processed

\section{Criterion 2 (A2) = criterion of Semen Amount Used in Artificial Insemination (IB)}

The condition of availability of semen (IB) in regency/municipality regions in DIY is calculated with the amount of semen available in each regency region in units of pack/year, Figures 6 and 7 show the condition of semen availability in DIY. 


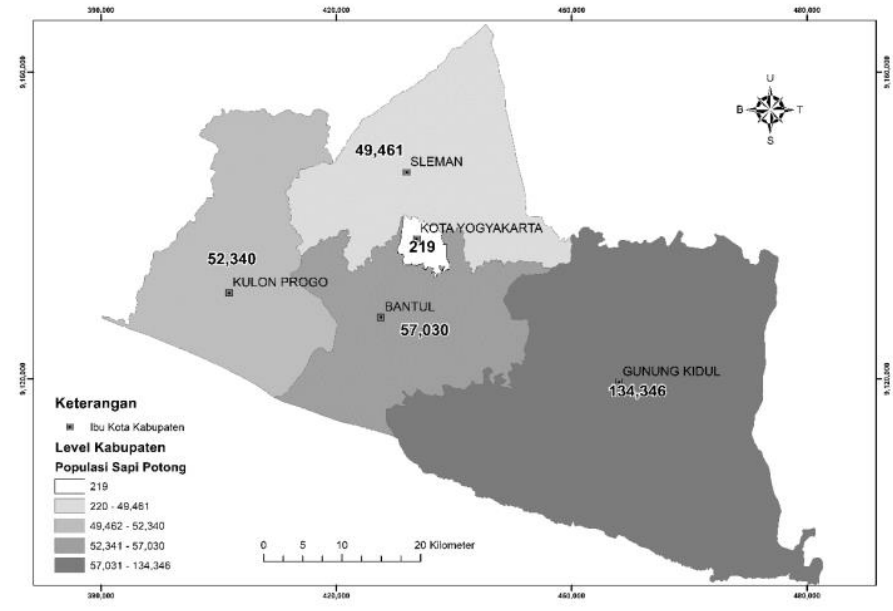

Figure 5. Spatial condition of cattle population in regency/municipality regions of DIY

Source: BPS and Agricultural Office DIY and BKPP DIY. Data processed

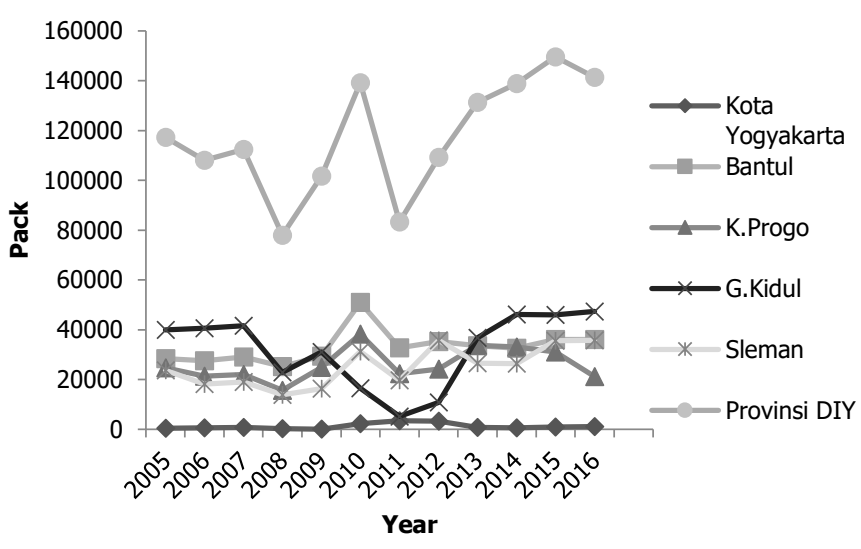

Figure 6. Artificial insemination semen availability per regency in DIY from 2005-2016

Source: BPS and Agricultural Office DIY and BKPP DIY. Data processed

Graphically, using Arch GIS 10.4.1 program, a description is obtained shown in Figure 7.

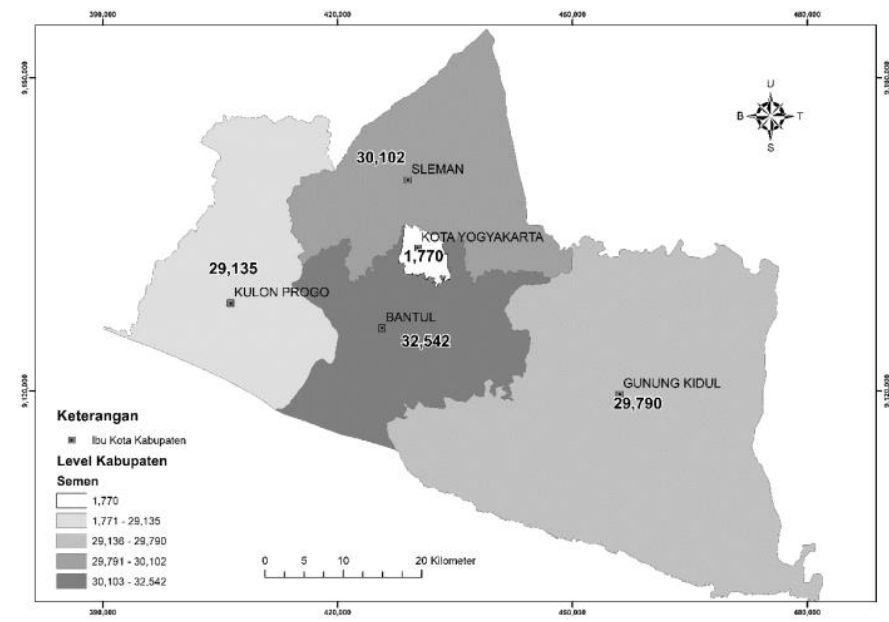

Figure 7. Spatial condition of semen (IB) availability in regency/municipality regions in DIY

Source: BPS and Agricultural Office DIY and BKPP DIY. Data processed

Figures 6 and 7 show the average availability of semen for IB, the highest is in Bantul regency with
32,542 packs/year, followed by Sleman regency with 30,102 packs/year, Gunung Kidul regency with 20,790 packs/year, and the lowest is in Yogyakarta municipality, with 1,770 packs/year.

\section{Criterion 3 (A3) = Pasture (HMT) Area Size}

An analysis based on the third parameter, that is, the availability of pasture (HMT) rumination area in DIY, the areas are shown in Figures 8 and 9.

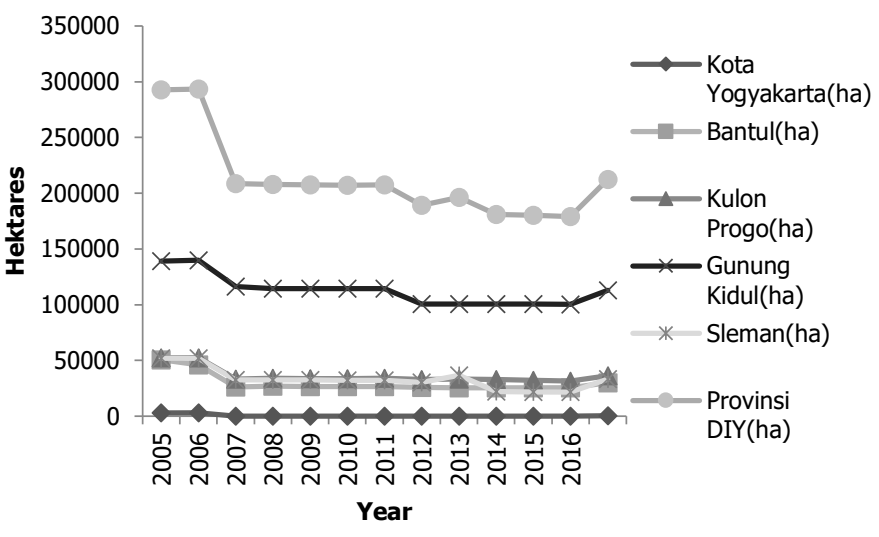

Figure 8. Availability of pasture rumination area in each regency in DIY from 2005-2016

Source: Badan Pusat Statistik (BPS); Agricultural Office, DIY, BKPP DIY. (Various sources, processed, 2017)

Availability of pasture rumination areas counted in this analysis doesn't include all types of field, but only five types of pasture provider field, namely paddy fields, moors, plantations, community forests, and state forests. The average width of the biggest pasture rumination provider areas from 2005 to 2016 is Gunung Kidul regency 97,259 ha/year. Followed by Sleman regency 34,270 ha/year, Kulon Progo regency 32,788 ha/year, Bantul regency 28,226 ha/year and lastly, Yogyakarta municipality with an average of 602 ha/year. Graphically, using Arch GIS 10.4.1 software, it is shown in Figure 9.

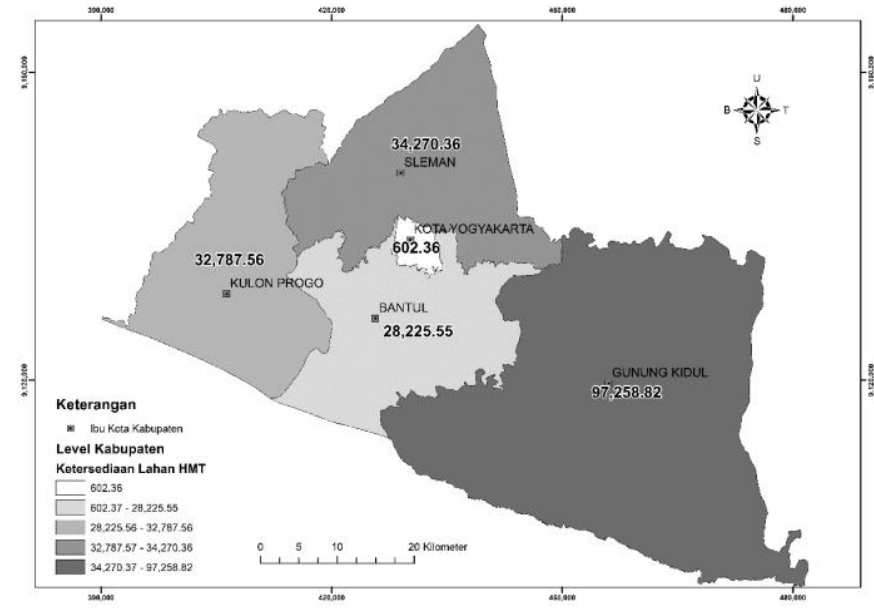

Figure 9. Spatial condition of pasture area availability in regencies/municipality in DIY

Source: Badan Pusat Statistik (BPS); Agricultural Office, DIY, BKPP DIY. (Various sources, processed, 2017) 


\section{Criterion 4 (D1) = Criterion of the Number of Cattle Entering DIY}

Multi criteria assessment using the fourth criterion, that is, the number of cattle entering regency/municipality areas in Yogyakarta Special Region using the data base from 2005-2016, shows that the biggest average number of beef cattle entering Gunung Kidul is 134,620 cows/year, followed by Sleman regency with 48,741 cows/year and consecutively after are Bantul regency with 7,203 cows/year, Kulon Progo regency with 5,103 cows/year, and Yogyakarta municipality with 223 cows/year, as shown in Figure 10.

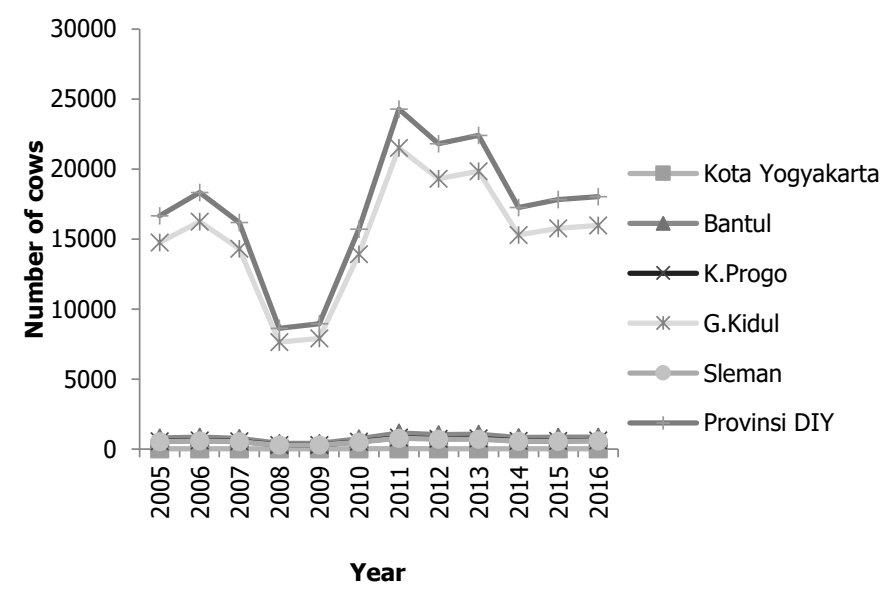

Figure 10. Number of beef cattle entering DIY from 2005-2016 Source: Agricultural Office DIY and BKPP DIY. (various years, processed)

Criterion of the number of cattle entering graphically presented using Arch GIS 10.4.1. software is shown in Figure 11.

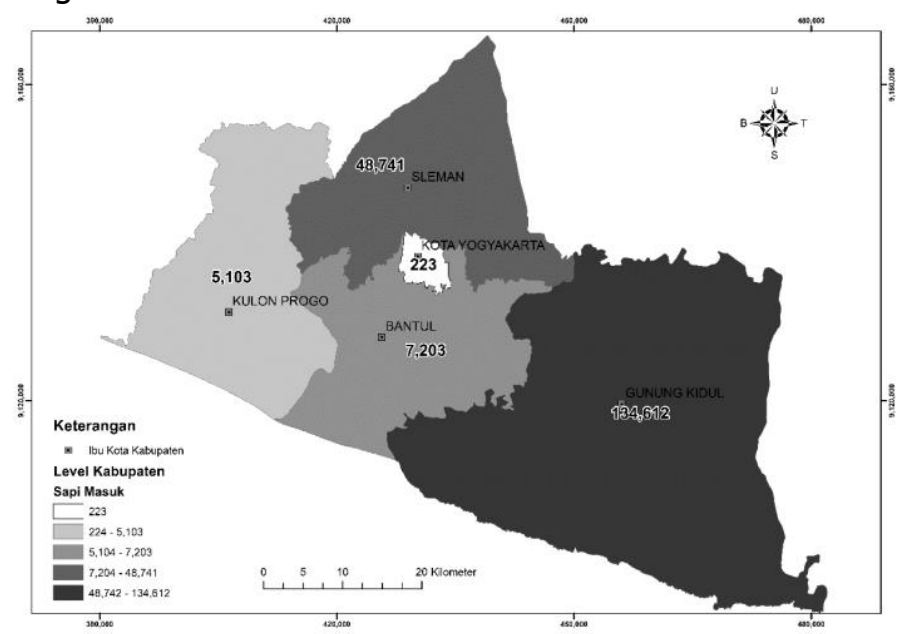

Figure 11. Spatial condition, the number of cattle enteringregency/municipality areas in DIY

Source: Agricultural Office DIY and BKPP DIY. (various years, processed)

\section{Criterion 5 (D2) = Number of Cattle Leaving DIY}

The spatial condition per regency/municipality area with data base parameter of the number of cattle leaving regency/municipality areas of DIY, measured based on the data from 2005-2016, shown in Figure 12.

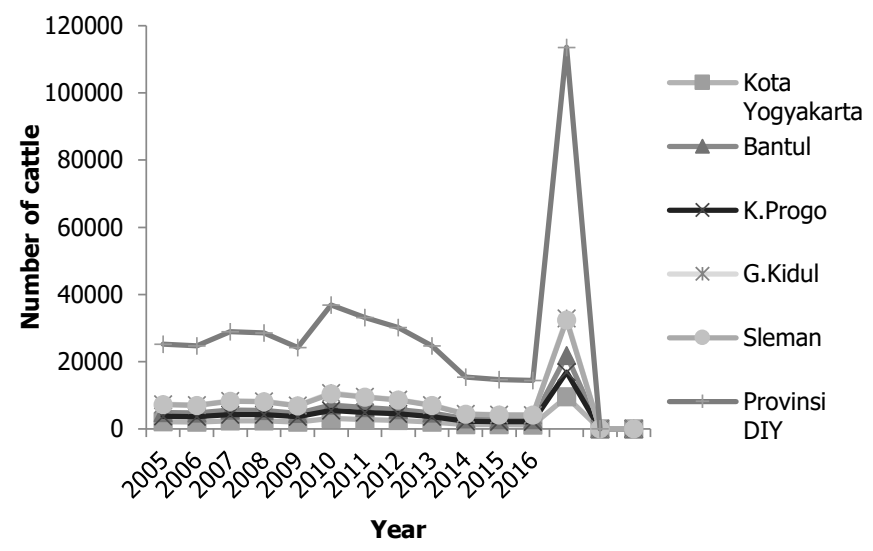

Figure 12. Number of cattle leaving DIY area from 2005-2016 Source: Agricultural Office DIY and BKPP DIY. (various years, processed)

Graphically, the spatial description is presented using Arch GIS 10.4.1, the number of cattle per regency area in DIY is shown in Figure 13.

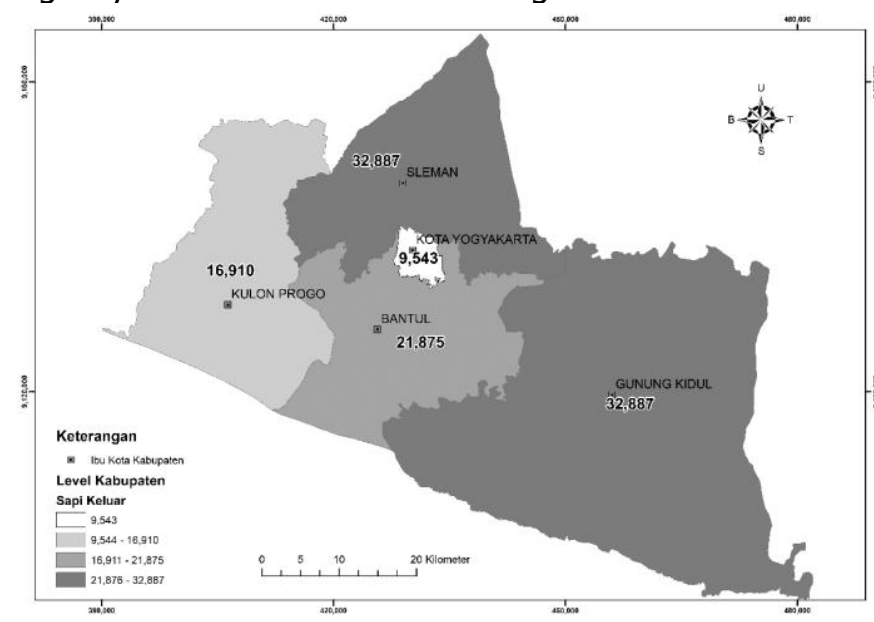

Figure 13. Spatial condition, the number of cattle leaving regency/municipality areas of DIY

Source: Agricultural Office DIY and BKPP DIY. (various years, processed

The highest average number of cattle leaving DIY is from Gunung Kidul regency, that is, 32,887 cows/year, followed by Sleman regency with 32,367 cows/year, and consecutively after are Bantul regency with 21,875 cows/year, Kulon Progo regency wit 16,910 cows/year, and the lowest number is from Yogyakarta municipality, with 9,543 cows/year.

The next step in this study is weighting. In weighting each criterion, there are three types of weighting provided in the ILWIS software, namely direct method (the value is determined by the decision maker), pairwise comparison (paired comparison with 
Table 2. SIG spatial-based MCA analysis results of beef availability in DIY

\begin{tabular}{lcccccc}
\hline Regency/Municipality & $\mathrm{A} 1$ & $\mathrm{~A} 2$ & $\mathrm{~A} 3$ & $\mathrm{D} 1$ & $\mathrm{D} 2$ & Index \\
\hline Kulon Progo & 0,389 & 0,889 & 0,333 & 0,036 & 0,684 & 0,466 \\
Bantul & 0,424 & 1,000 & 0,286 & 0,052 & 0,472 & 0,447 \\
Gunung Kidul & 1,000 & 0,911 & 1,000 & 1,000 & 0,000 & 0,782 \\
Sleman & 0,367 & 0,921 & 0,348 & 0,361 & 0,000 & 0,399 \\
Kota Yogyakarta & 0,000 & 0,000 & 0,000 & 0,000 & 1,000 & 0,200 \\
Max value & 134.346 & 32.542 & 97.259 & 134.612 & 32.887 & 9543 \\
Min value & 219 & 1770 & 602 & 223 & $20 \%$ & $20 \%$ \\
Weight & $20 \%$ & $20 \%$ & $20 \%$ & + & \\
Characteristics & + & + & + & & \\
\hline
\end{tabular}

weighting model when y), and rank-ordering (consisting of expected value model and rank sum method model). In this stage, because the expected weighting is balanced, direct method can be used. The balanced results of each criterion is weighted $20 \%$.

From MCA analysis result, a value assessment is performed with the index value of beef availability potential per region and per parameter throughout DIY, and a conclusion is drawn that the region with the highest potential is Gunung Kidul regency, as can be seen in Table 2

The final step in MCA analysis is giving appraisal with an index value, and the result shows the most potential region and the least potential region in terms of resources to provide beef cattle in DIY area. Table 2 and Figure 14 show that with a five-criteria parameter, namely beef cattle population (cows); IB semen availability (packs); rumination area availability (hectares); number of cattle entering DIY (cows); and number of cattle leaving DIY (cows), the result show that the most potential region is Gunung Kidul regency, with an index value of 0.782 , and the least potential region is Yogyakarta municipality with an index value of 0.200 , as shown in Figure 14.

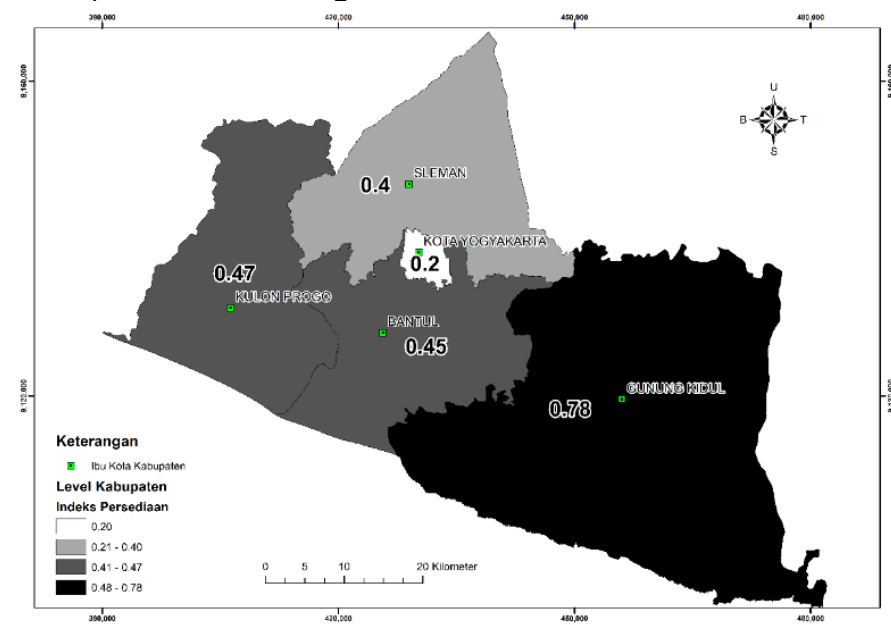

Figure 14. Result of MCA spatial empirical study of beef availability potential in DIY
From this study, it is shown that there are three regions in DIY with high potential for beef agribusiness, namely Gunung Kidul, Kulon Progo and Bantul regencies. In the future, the three regions can be established as triangle area of beef cattle business center with each regency having its own characteristics. Gunung Kidul regency as the provider of beef cattle seeds, Kulon Progo regency as the provider of pasture rumination area, and Bantul regency, which has the most number of slaughter houses, is made as the center provider of fresh and processed beef. The government should be able to realize this, so that in the future beef availability in DIY can be fulfilled from these potential regencies. If the market runs evenly, not only will DIY be able to provide beef continuously, but it will also be able to achieve self-sustained beef supply one day.

\section{CONCLUSION}

An analysis using Multi Criteria Analysis (MCA) of the Spatial Geographical Information System (SSIG) is conducted on all regency and municipality in Yogyakarta Special Region, which consist of five regions (Sleman regency; Bantul regency; Kulon Progo regency, Gunung Kidul regency; and Yogyakarta municipality). The research results show that the most potential region in developing beef cattle agribusiness, especially on the supply side, is Gunung Kidul regency, and the least potential region is Yogyakarta municipality region, which is also known as Yogyakarta City. With these results, stakeholders, especially DIY provincial government can develop regions with the most potential as the center for beef cattle breeding. Later, the center can be assigned as the center of beef cattle based agribusiness development center. It is expected that beef availability in DIY can be maintained and can harmoniously advance with the growing demand for beef in DIY. 


\section{ACKNOWLEDGEMENT}

The writer owes a debt of gratitude to the Director of Research and Community Service Department, Directorate General of Research and Development Enforcement, Ministry of Research, Technology and Higher Education who provided the research grant in 2017 budget year.

\section{REFERENCES}

Akinci, H., Ozalp, A. Y., \& Turgut, B. (2013). Agricultural land use suitability analysis using GIS and AHP Technique. Journal Computer and Electronic in Agriculture, 972013), 71-82. Doi: 10.1016/j.compag.2013.07.006.

Biro Pusat Statistik (BPS). (2008). Statistik Usaha Indonesia. http://www.bps.go.id. [20 Desember 2014].

Biro Pusat Statistik (BPS) DIY. (2015). Perkembangan Eksport Import DIY Bulan Januari 2015. Berita Resmi Statistik. No. 14/02/34/Th.XVII. 16 Februari 2015.

Biro Pusat Statistik (BPS) DIY. (2016). DIY dalam Angka Bulan Juli 2017. Laporan tahunan non publikasi, hal. 30-68.

Chakhar, S. \& Mousseau, V. (2007). Spatial multicriteria decision making. LAMSADE: International Journal of Publications 1-8. Doi: 10.1007/978-0-387-35973-1.

Chomitz, K. M. \& Gray, D. A. (2010). Roads, land use, and deforestation: a spatial model applied to belize. The World Bank Economic Review, 10(3), 487-512. Doi: 10.1093/wber/10.3.487.

Dodgson, J., Spackman, M., Pearman, A., \& Phillips, L. (2009). Multi-Criteria Analysis: $A$ Manual. London School of Economics and Political Science, Department of Economic History.

Irwansyah (2013). Sistem Informasi Geografis: Prinsip Dasar dan Pengembangan Aplikasi, Digibook Printing and Publising, Yogyakarta.

Juppenlatz \& Tian (1996). Geografic information systemin application model. Suistanable Cities and Society Journal 14(1996): 12-25.

Kuncoro, M. (2002). Analisis Spasial dan Regional Studi Aglomerasi dan Kluster Industri Indonesia. Unit Penerbit dan Pencetak (UPP) AMP YKPN, Yogyakarta.

Kuncoro, M. (2006). Ekonomi Pembangunan Teori, Masalah, dan Kebijakan. Unit Penerbit dan Pencetak (UPP) STIM YKPN, Yogyakarta.

Neuwirth, C., Peck, A. \& Simonovic, S. P. (2015). Modelling structural change in spatial system dynamics: a daisyword example. Journal of Environmental Modelling and Software, 65(2015), 30-40. Doi: 10.1016/j.envsoft.2014.11.026.

Niedertsscheider, M., Kuemmerie, T., Muller, D., \& Erb, K. H. (2014). Exploring the effetct of drastic institutional and socio-economic changes on land system dynamics in Germany between 1883 and 2007. Global Environmental Change Journal, 28(2014), 98-108. Doi: 10.1016/j.gloenvcha.2014.06.006.

Tarigan, R. (20080. Perencanaan Pembangunan Wilayah. Edisi Revisi. Percetakan P.T. Bumi Aksara. Jakarta.

Zhang, X., Izaurralde, R. C, Manowitz, D. H., Sahajpal, R., \& West, T. O. (2015). Regional scale cropland carbon budgets: evaluating a geospatial agrivultural modelling system using inventory data. Journal Environmental Modelling and Software, 63(2015), 199-216. Doi: 10.1016/j.envsoft.2014.10.005. 